tence-" The world will little note nor long remember what we say here; but it can never forget what they did here."

\section{HeNRY CREW}

NORTHWESTERN UNIVERSITY

CHARLES REID BARNES

Charles Reid Barnes was born at Madison, Ind., September 7, 1858, and died at Chicago, Thursday, February 24, 1910. He attended Hanover College, where he graduated with the degree of A.B. in 1877, being the valedictorian of his class. He was a student of Professor Coulter, with whom he was henceforth intimately associated professionally and otherwise until his death. After graduation he studied at Harvard University with Professor Gray, who regarded him as a man of great promise. In 1880 Barnes returned to Hanover College, where he was given the degree A.M. That same year he entered upon an instructorship of natural science at the high school, Lafayette, Ind., and later at Purdue University, where he was promoted to a professorship in 1882. In 1885 his chair was changed from natural science to botany and geology. In the year 1885-6 Professor Barnes again spent some time at Harvard University, and his alma mater in 1886 conferred upon him the degree Ph.D. In 1887 he was called to the chair of botany at the University of Wisconsin, whence in 1898 he was called by the University of Chicago to occupy its newly created chair of plant physiology, and here he remained until his death. From 1883 until his death he was associated with Professor Coulter in the editorship of The Botanical Gazette.

Professor Barnes was always prominently connected with the various scientific societies, having become a member of the American Association for the Advancement of Science in 1884 and a fellow in 1885 . In 1890 he was secretary of the Botanical Club of the American Association for the Advancement of Science, and was secretary of the Botanical Society of America from its inception at Brooklyn from 1894 until 1898. In 1894 he served as secretary of Section G, in 1895 as secretary of the council of the American Association for the Advancement of Science, and in 1896 as general secretary of the American Association for the Advancement of Science. In 1898 he served as vice-president for Section G, American Association for the Advancement of Science, giving his retiring address at Columbus in 1899 on "The Progress and Problems of Plant Physiology." In 1903 he served as president of the Botanical Society of America, giving his retiring address at Philadelphia in 1904 on "The Theory of Respiration." In 1905 Professor Barnes served as a delegate from Section G, American Association for the Advancement of Science, to the international Botanical congress at Vienna. $\mathrm{He}$ was also a member of the American Society of Naturalists and of the Botanists of the Central States, and was in turn a member of influence in the state scientific academies of Indiana, Wisconsin and Illinois.

As a botanical contributor Professor Barnes began his career in a modest way in The Botanical Gazette in 1877, his first contributions, entitled "Notes," having to do chiefly with annotated lists of plants and additions to county floras, quite in the manner of the time. As early as 1879, however, some of his contributions reveal a strong physiological bent, the necessity of devices for accurate experimentation appealing to him then and ever afterward with unusual force. From 1883, when he became editorially connected with The Botanical Gazette, he gave freely of his time and energy to that journal. Much of the remarkable success of this periodical is due to his editorial genius; his trenchant English, and his insistence on accurate statement and mechanical perfection have for many years been reflected on almost every page. Perhaps no botanical reviewer has been so fearless as was Professor Barnes; frank but friendly disapproval of all that seemed bad, whether in fundamental principles, in statement of fact, or in mechanical alignment, was as natural to him as is fulsome praise to most reviewers. Possibly his greatest service to American botany was in his many-sided work on The Botanical Gazette.

Professor Barnes was first generally known 
to the botanical fraternity through his taxonomic work on mosses, his first publication in this field being an "Analytic Key to the Genera of Mosses," published in 1886 as a bulletin of Purdue University; the following year was published a "Revision of the North American Species of Fissidens." In 1890 there was issued by the Wisconsin Academy of Science his "Artificial Keys to the Genera and Species of North American Mosses"; a revision of this work by Barnes and Heald appeared in 1897. There can be no doubt that these keys have greatly stimulated bryological study in this country, because the classic manual of the mosses (Lesquereux and James) is full of difficulties to all but the specialist in the group. A revision of Dicranum by Barnes and True practically completed the author's work in this field. While at Chicago Professor Barnes became greatly interested in the special morphological problems presented by the mosses and liverworts, and for several years there was offered in cooperation with Dr. Land a course in the special morphology of the bryophytes. In connection with this work Drs. Barnes and Land made extensive field studies and collections in Mexico in 1906 and 1908. There had already appeared two joint papers, one on "The Origin of Air Chambers" and the other on "The Origin of the Cupule of Marchantia"; several other joint papers are in various stages of completion, and are to be issued by the junior author. A general work on the special morphology of the bryophytes had been projected for the immediate future.

In plant physiology Professor Barnes's chief contributions were as a critical reviewer, as a teacher and effective guide in critical research, and as a sponsor for certain points of view. He was early a champion of the restricted use of the term plant food, as opposed to the broader usage, including water and salts. $\mathrm{He}$ also advocated long ago the use of the term photosynthesis (or photosyntax) in place of assimilation for the first stages in food-making, and he consistently advocated the restriction of sex terms to sex organs. The vice-presidential address of 1899 , and even more the presidential address of 1904, gave stimulating physiological points of view much in advance of current usage. To few is it given to be so effective as a teacher and guide in critical research, and particularly to make clear the actual status of the subject when foggy and uncertain, as is the case in so many divisions of physiology. The botanists whom Professor Barnes has trained will through their teaching and their investigation carry on his ideals and reflect his powerful personality for yet many years. It is a source of intense gratification to his many botanical friends that Professor Barnes was able to revise the final proofs on the physiological part of a general work on botany that is expected soon to appear from the Hull Botanical Laboratory. In this there will be preserved the essence of his physiological point of view and something of his cogent reasoning and lucid style.

In 1898 Professor Barnes issued a botanical text-book for secondary schools, entitled, "Plant Life, Considered with Special Reference to Form and Function." This little book was about the first to deal particularly with physiology and ecology as subjects for study in secondary schools, and found a teaching public unprepared to use it, though the viewpoint here presented now dominates almost everywhere. A briefer edition of this volume, entitled, "Outlines of Plant Life," appeared in 1900 .

To his botanical colleagues the death of Professor Barnes seems peculiarly premature, as he died from the effects of an accidental fall in full vigor and health, and just as he was about to round up in monographic form the results of years of study on the bryophytes. It was to have been expected also that before very long he would have incorporated his lectures to advanced classes on "Plant Physics," "Plant Chemics" and "Growth and Movement" into permanent form. To those who knew Professor Barnes intimately it is known that one of the foremost of our botanists has gone, a man great in many lines, and one who, in spite of his frank criticism and pitiless logic, was more than all a friend.

\section{Henry C. Cowles}

